\title{
Damage by Tibraca limbativentris (Hemiptera: Pentatomidae) to rice in Southwestern Colombia ${ }^{1,2}$
}

\author{
Alberto Pantoja ${ }^{3}$, Mónica Triana ${ }^{4}$, Harold Bastidas ${ }^{4}$, \\ César García ${ }^{4}$ Olga I. Mejia ${ }^{4}$ and Myriam C. Duque
}

J. Agric. Univ. P.R. 91(1-2):11-18 (2007)

\begin{abstract}
Action thresholds for Tibraca limbativentris Stall (TL) on rice were calculated to be 8.8 and 25.8 TL per 10 sweep nets for 30- and 40-day old plants, respectively. Population dynamics of TL at two localities in Valle del Cauca, Colombia, indicated a density of 1.2 TL per sweep (12 TL per 10 sweeps). Densities equal to the calculated action thresholds were not observed in rice fields in Valle del Cauca, Colombia, during the study period. Infestation to 15- or 20-day-old plants did not cause yield reductions, thus suggesting that scouting for this pest should be concentrated on 25- to 40-day-old plants.
\end{abstract}

Key words: rice, damage, yields, Tibraca limbativentris

\section{RESUMEN}

Daño por Tibraca limbativentris (Hemiptera: Pentatomidae) al arroz en el suroeste de Colombia

El umbral de acción para Tibraca limbativentris Stal (TL) en arroz fue calculado en 8.8 y $25.8 \mathrm{TL}$ por 10 pases de red entomológica para plantas de 30 y $\mathbf{4 0}$ días, respectivamente. Estudios de la densidad poblacional de TL en dos localidades del Valle del Cauca, Colombia, indican densidades de 1.2 TL por pase de red entomológica (12TL por 10 pases de red). Densidades equivalentes al umbral calculado no se observaron en los arrozales del Valle del Cauca, Colombia, durante los años de estudio. Infestaciones a plantas de 15 y 20 días de germinadas no se reflejan en daño o rendimiento, lo que sugiere que las evaluaciones para densidad insectil deben ser en plantas de 25 a 40 días de germinadas.

Palabras clave: arroz, daño, rendimiento, Tibraca limbativentris

${ }^{1}$ Manuscript submitted to Editorial Board 10 August 2006.

${ }^{2}$ The authors recognize comments by L. DeFoliart, A. Hagerty, S. Emmert and D. Fielding, USDA, ARS Alaska on an earlier version of this manuscript.

3USDA, ARS, SARU, P.O. Box 757200, Fairbanks, AK 99775. Work conducted while at CIAT, Cali, Colombia.

${ }^{4}$ Biometric Unit, Centro Internacional de Agricultura Tropical (CIAT) Rice Program, A.A. 6713, Cali, Colombia, South America. 


\section{INTRODUCTION}

Tibraca limbativentris Stall (TL) is considered an important rice pest in Argentina, Brazil, Colombia, Peru, Ecuador, the Dominican Republic, and Venezuela (Trujillo, 1991; Aponte et al., 1992; FEDEARROZ, 1993, 1995; Prando et al., 1993; Pantoja et al., 1995; Usta et al., 1995; Ferreira et al., 1997; Pérez, 1997; González, 1998; Vivas and Clavijo, 2000; Pantoja et al., 2005). In Latin America Tibraca spp. is probably the most challenging insect group for which to develop action thresholds (AT). Both adult and nymph Tibraca spp. feed on plants, causing a condition known as whiteheads and deadharts (Heinrichs and Miller, 1991; Pantoja, 1997). The damage is similar to that described for stemborers (Heinrichs and Miller, 1991). Affected panicles are lost during harvesting and threshing; therefore, yield is affected. On rare occasions plant death occurs.

In spite of the reported agricultural significance of stink bugs in the region, few data are available on the economic importance and damage functions of $T$. limbativentis in rice. In Colombia and Venezuela farmers apply insecticide for Tibraca spp. control, but action thresholds are based on the presence of white panicles (Aponte et al., 1992; FEDEARROZ 1993, 1995), not on insect density. However, the presence of whiteheads in the field is a symptom of damage that occurred earlier, during the filling stage of grain development, and is not a reliable indicator of insect presence or population density (Pantoja, 1997). Information on the effect of insect density on yield and damage is of importance in developing action thresholds (AT) and integrated pest management (IPM) programs. In this work, we report the effect of T. limbativentris on yield reductions in irrigated rice in Southwestern Colombia.

\section{MATERIALS AND METHODS}

Adult T. limbatriventis (TL) used in the experiment were obtained from a colony at Palmira, Colombia (Pantoja et al., 2005). Insects were confined to 15-, 20-, 30-, and 40-day-old plants of Oryzica 3, a popular variety of rice in Colombia. Rice was planted directly on 0.5-square meter trays kept under greenhouse conditions. Plants were thinned to a uniform density of four plants per tray. Insects were confined within a lumite cage supported by a frame of PVC and wire. Cages were anchored to the soil with metallic stakes and a permanent flood was established. Each cage was infested with the equivalent of zero, four, eight, 12 or 16 insects per tray. A constant infestation rate was maintained for three days by daily replacing dead insects. Three days represent the average time it takes a farmer to detect the infestation and apply control measures (Pantoja et al., 1992). A completely ran- 
domized block design with four replicates per plant age was used. Each tray represented a replicate.

Plants were inspected for oviposition. Egg masses were counted and segregated by leaf number and position on the leaf. The percentage of egg masses per leaf was calculated. After the three-day infestation period, plants were sprayed with a contact insecticide to eliminate insects. Cages were left undisturbed until panicle maturity. Panicles with symptoms of insect damage (whiteheads and deadharts) were counted and discarded (Heinrichs and Miller, 1991; Pantoja, 1997). The remaining panicles were harvested and threshed by hand. Rice yields were measured after drying kernels for $72 \mathrm{~h}$ at $65^{\circ} \mathrm{C}$. The percentage of damaged panicles was calculated. Data were analyzed by using PROC REG (SAS, 1999).

To establish the relative insect density under field conditions, we collected TL adults with a standard insect net (38-cm diameter) at two localities, Jamundi and Ginebra, Valle del Cauca Department, Colombia. A total of 80 fields were evaluated from May 1989 to September 1992. Samples were collected weekly or biweekly, depending on availability of rice fields. Six samples were collected from each randomly selected field. Samples consisted of 100 sweeps. Each horizontal stroke of the net in either direction was considered one sweep and was completed with each forward step. Sampling started 15 days after planting and ended at harvest. Insects were transported to the laboratory at 'Centro Internacional de Agricultura Tropical', Cali, Colombia, and sorted by species. Nymphs cannot be identified to species level; therefore, only adults were considered for the density counts.

\section{RESULTS AND DISCUSSION}

Insect feeding on 15- and 20-day-old plants showed no significant effect on yield or plant damage (Tables 1, 2; Figures 1, 2). Significant yield reductions and significant increases in damage percentage (white panicles) were detected for 30- and 40-day-old plants. The lack of significant yield effects or damage for the 15-and 20-day-old plants suggests that insect damage early in the vegetative stage of growth has little effect on yield. Insect densities of up to 1,000 T. limbativentris per hectare did not significantly affect yields if feeding occurred within 30 days of germination, thus suggesting that the presence of T. limbatriventis during the early stage of plant development does not warrant control measures. The lack of yield loss at the early plant stage of development can be attributed to plant recovery during the vegetative stage (Arciniegas et al., 1999). Early damage before panicle elongation (Tascon and García, 1985) might also affect the ability of the 
TABLE 1.-Regression parameters for rice yield as affected by Tibraca limbatriventis on rice plants of different ages, Cali, Colombia.

\begin{tabular}{lcrcc}
\hline Plant age (days) & Intercept & Slope & $\mathrm{P}>\mathrm{F}$ & $\mathrm{R}^{2}$ \\
\hline 15 & 578.3 & 0.80 & 0.7806 & 0.02 \\
20 & 704.0 & -0.52 & 0.5448 & 0.09 \\
30 & 646.0 & -1.20 & 0.0316 & 0.72 \\
40 & 1031.0 & -1.80 & 0.0152 & 0.81 \\
\hline
\end{tabular}

pest to interfere with panicle development or cause white panicles. However, this theory needs further research and was not contemplated in this study.

In Colombia the mean yield per hectare is about $7.0 \mathrm{t}$ (Tascon and García, 1985); the cost of rice is about $\$ 110.00 / t$. The average cost for terrestrial application of pesticides is estimated at $\$ 28 /$ ha $(\$ 32 /$ ha for aerial application); at current rice prices that will be approximately $3.2 \%$ of the average rice yield (3.6\% for aerial application). This amount represents approximately $224 \mathrm{~kg}$ of rice. The number of insects required to reduce yield to an amount equal to the cost of control or action threshold (AT) (224 kg/ha) in 30- and 40-day-old plants (Figure 1; Table 1) can be calculated:

30-day-old plants

$7 \mathrm{t}-2.2 \mathrm{t}=6.5-1.20 \mathrm{TL}$

$\mathrm{TL}=2.8$ insects 40-day-old plants

$$
\begin{aligned}
& 7 \mathrm{t}-2.2 \mathrm{t}=10.31-1.80 \mathrm{TL} \\
& \mathrm{TL}=6.2 \text { insects }
\end{aligned}
$$

At a planting rate of $100 \mathrm{~kg}$ seed/ha, 10 sweeps will cover approximately 4,200 plants (10 sweeps cover approximately 4.2 square meters). The number of TL required to cause a yield loss equivalent to the cost of control will be 8.8 and 25.8 TL per 10 sweeps for 30 - and $40-$ day-old plants, respectively. According to Usta et al. (1995), each insect will affect 0.49 panicles per day for a yield reduction of $266 \mathrm{~kg} / \mathrm{ha}(\mathrm{AT}=$ two insects per square meter or 8.4 insects per 10 sweeps). However, Usta et al. (1995) did not state the plant age, infestation rate, and con-

TABLE 2.-Regression parameters for percentage of plants with white panicles caused by Tibraca limbatriventis on rice plant of different ages. Cali, Colombia.

\begin{tabular}{lcccc}
\hline Plant age (days) & Intercept & Slope & $\mathrm{P}>\mathrm{F}$ & $\mathrm{R}^{2}$ \\
\hline 15 & 29.1 & 0.073 & 0.0587 & 0.63 \\
20 & 47.7 & 0.038 & 0.4670 & 0.13 \\
30 & 64.5 & 0.107 & 0.0591 & 0.63 \\
40 & 38.7 & 0.099 & 0.0097 & 0.84 \\
\hline
\end{tabular}




\section{$15 \mathrm{D} \square 20 \mathrm{D} \triangle 30 \mathrm{D} \circ 40 \mathrm{D}$}

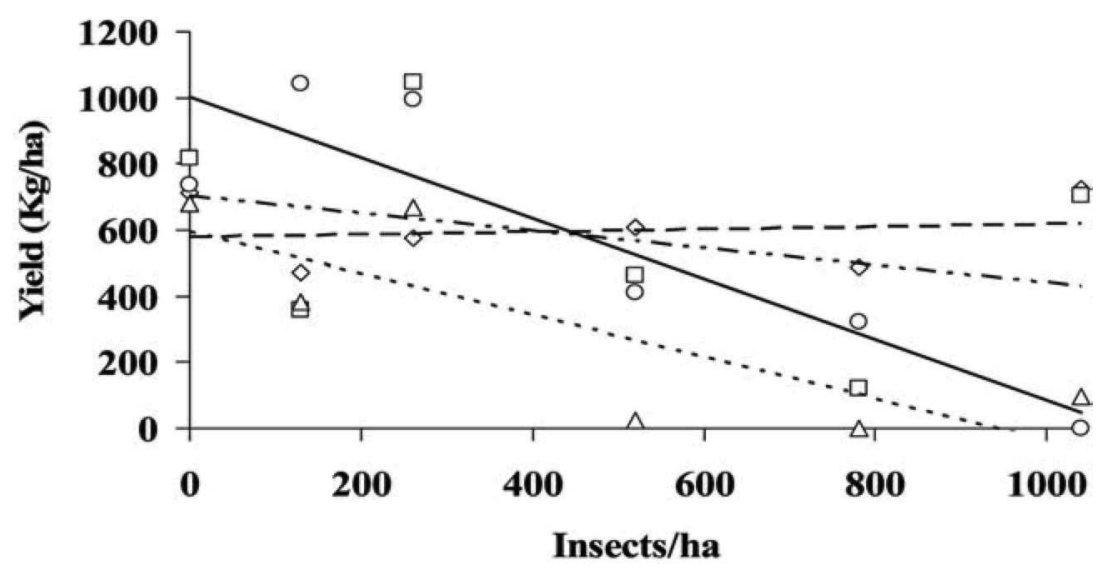

FIGURE 1. Rice yield (kg/ha) as affected by Tibraca limbativentris on rice plants of different ages. Cali, Colombia.

ditions under which the trial was conducted. A two-year study of the population dynamics of TL at two localities of Valle del Cauca, Colombia (Jamundi and Ginebra), indicated a density of 1.2 TL per sweep (Figure 3 ), thus suggesting that this pest will rarely reach damaging levels.

Fifty-six percent of the eggs were deposited on the abaxial side of the leaf, whereas $44 \%$ were deposited on the adaxial side. Older leaves are preferred for oviposition. Sixty-seven percent of the eggs were deposited on leaf number one. Leaves number 2 and 3 each received $11 \%$ of the eggs. Only $11 \%$ of the eggs were deposited on leaves 4 and $5(5.5 \%$ on each). No report on egg distribution is available on TL to compare with that of our study. The data indicate that sampling for TL oviposition should concentrate on the area near the soil or water surface. Oviposition in the lower canopy might be related to TL habits. This insect is usually found in the lower part of the rice plants close to the soil surface (Pantoja, 1995). This fact will complicate sampling in large areas since scouts usually inspect the upper part of the canopy.

Our results indicate that high TL densities ( 8 and 25 TL per 10 sweeps for 30 - and 40-day-old plants, respectively) are required to cause yield reductions in rice if the damage occurs to 40-day-old plants. Those densities were not seen in the Jamundi and Ginebra areas during the years 1989-1992, thus suggesting that this pest will rarely reach damaging levels in the area of this study. However, no recent population dynamics studies are available to establish whether current TL 


\section{$15 D \square 20 D \triangle 30 D \circ 40 D$}

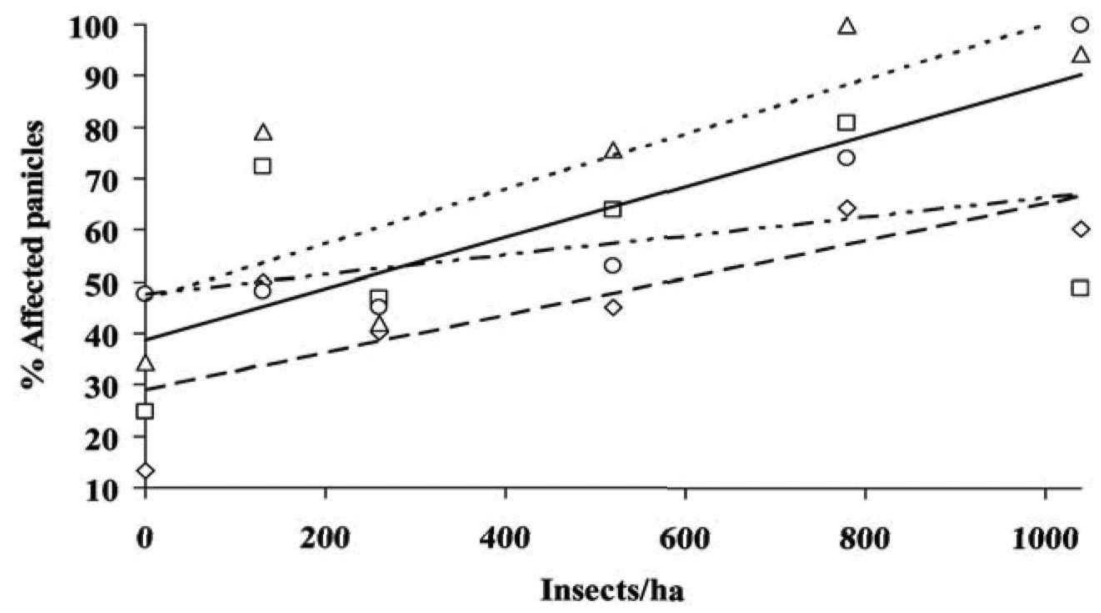

FIGURE 2. Percentage of white panicles (damage) caused by Tibraca limbativentris on rice plants of different ages. Cali, Colombia.

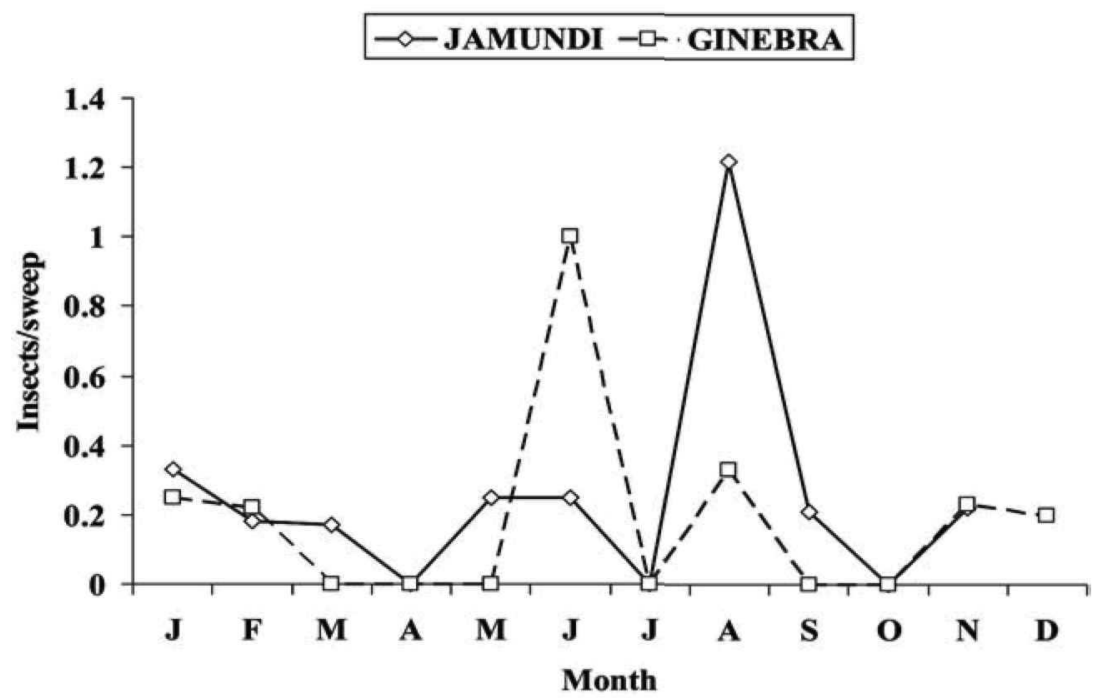

FIGURE 3. Population dynamics of Tibraca limbativentris at two localities of Valle del Cauca, Colombia, 1989-1992. 
densities warrant control in the area of study. Several authors (FEDEARROZ, 1995; Pérez, 1997; Usta et al., 1995) indicate that the pest is increasing in density in other areas of Colombia and the region. Additional research is needed to establish why damage early in the vegetative stage of plant development has no effect on yield. Further research is needed to determine current insect densities in rice fields in the Jamundi and Ginebra regions. Further work should also examine AT under field conditions. The lack of yield reduction in 15- and 20-dayold plants indicates that sampling for TL should be focused on 25- to 40day-old plants. This information will save scouting time as farmers and scouts will have a precise time and site to survey for this pest.

\section{LITERATURE CITED}

Aponte, O, L. E. Escalona, L. E. Vivas, L. M. Ramírez and F. P. Freitez, 1992. Manejo Integrado de Artrópodos Plaga en el Cultivo de Arroz en Venezuela. CIAT, Cali, Colombia.

Arciniegas, I. C., A. Pantoja, C. García and M. C. Duque, 1999. Umbral de acción de Hortencia similis Walker y Draeculacephala soluta Gibbons (Homoptera: Cicadellidae) en el cultivo de arroz en el Valle del Cauca, Colombia. J. Agric. Univ. P.R. 83:65-74.

FEDEARROZ, Federación Nacional de Arroceros, 1993. Estudios biológicos y fluctuación poblacional de Tibraca limbativentris (Stal). Correo FEDEARRROZ, Notitécnicas 4(37):4-5.

FEDEARROZ, Federación Nacional de Arroceros, 1995. Nivel de daño económico y hospederos alternos de Tibraca limbativentris (Stal) en arroz. En: Informe Anual FEDEARROZ 1995. Santa Fé de Bogotá, Colombia. pp. 106-111.

Ferreira, E., F. J. P. Zimermann, A. Baeta dos Santos and B. Pereira das Neves, 1997. O percevejo-do-colmo na cultura do arroz. EMBRAPA-CNPAF, Goiania, Goias, Brazil, Documento \#75.

González, M., 1998. La tibraca, nuevo reto para los arroceros. Fersan Informa (República Dominicana), No. 73, año XIX, junio 1988. pp. 17-19.

Heinrichs, E. A. and T. A. Miller, 1991. Rice Insects: Management Strategies. SpringerVerlag, New York.

Pantoja, A., E. Daza and M. C. Duque, 1992. Efecto de Oebalus ornatus (Sailer) \& Oebalus insularis (Stal) (Hemiptera: Pentatomidae) sobre el arroz: una comparación entre especies. MIP (Costa Rica). 26:31-33.

Pantoja, A., E. Daza, C. García, O. I. Mejía and D. Rider, 1995. Relative abundance of stink bugs (Hemiptera: Pentatomidae) in south western Colombia rice fields. J. Entomol. Sci. 30:463-467.

Pantoja, A., 1997. Artrópodos relacionados al arroz en América Latina. In: MIP en ARROZ. A. Pantoja, A. Fischer, F. Correa, L. R. Sanint y A. Ramírez. CIAT Publication 292. CIAT, Cali, Colombia. pp. 59-98.

Pantoja, A., M. Triana, H. Bastidas, C. García and M. C. Duque. 2005. Development of Tibraca obscurata and Tibraca limbativentris (Hemiptera: Pentatomidae) on rice in Southwestern Colombia. J. Agric. Univ. P.R. 89:221-228.

Pérez, C. R., 1997. Aspectos bioecológicos de chinches. Arroz (Colombia) 46 (411):20-21.

Prando, F. H., H. Kalvelange and R. A. Ferreira, 1993. Ciclo de vida de Tibraca limbativentris, 1860 (Hemiptera: Pentatomidae) em condicoes de laboratorio. Revista Brasileira Entomologia 37(2):335-339. 
SAS Institute, 1999. The SAS system version 8 for windows. SAS Institute, Cary, NC.

Tascon, E. and E. García, 1985. Arroz: Investigación y producción. CIAT/PNUD, Cali, Colombia. 196 pp.

Trujillo, M. R., 1991. Chinche grande del Arroz: Biología y Control. Instituto Nacional de Tecnología Agropecuaria, Estación Experimental Agropecuaria, Corrientes, Argentina, Mayo 1991. 16 pp.

Usta, A., C. R. Pérez and V. Lobaton, 1995. Nivel de daño económico y hospederos alternos de Tibraca limbatriventis (Stal) 1860 en ARROZ. In: Proceedings XXII Congreso de la Sociedad Colombiana de Entomología. Santa Fé de Bogotá, Colombia.

Vivas, L. E. and S. Clavijo, 2000. Fluctuación poblacional de Tagosodes orizicolus (Muir) 1926 (Homoptera: Delphacidae) en el sistema de riego Río Guarico, Calabozo, Estado Guarico, Venezuela. Boletín Entomológico Venezolano 15(2):217-227. 